\title{
LA IMAGEN DEL PODER EN LAS MINIFICCIONES DE EDUARDO GALEANO
}

\author{
Nana Rodríguez Romero* \\ Universidad Pedagógica y Tecnológica de Colombia
}

\section{Resumen}

A través de un corpusde textos conocidos como minificciones, del escritor Eduardo Galeano, se realiza un análisis que permite desbrozar el lugar del poder desde sus cualidades de origen, naturaleza básica y manifestaciones, a la luz del pensamiento de MichelFoucault, pues el poder como problema no sólo configura una cuestión teórica, sino que es parte de nuestras experiencias, en este caso desde la recepción de la literatura.

Palabras clave: Galeano, Poder, minificción, Foucault.

\begin{abstract}
The image of power in the short-short fiction of Eduardo Galeano.

Based on a corpus of the renowned short-short fiction of Eduardo Galeano, we will analyze the place of power focusing on its qualities of origin, basic nature and manisfestations, under the light of the theories of Michel Foucault, where power is a problem that not only configures a theoretical question, but that also runs through our experiences, in this case of the reception of literature.
\end{abstract}

Key words: Galeano, power, short-short fiction, Foucault.

* Proyecto de investigación: Poder y mundo contemporáneo, Grupo Filosofía, Educación y Sociedad.luzmarinanana@gmail.com 


\section{Introducción}

Abordar el tema de la imagen del poder en la obra de Galeano, escritor notable por su obra literaria crítica, comprometida, satírica e irónica, enmarcada en la minificción y el minicuento, exige desarrollar algunos tópicos para iluminar el objetivo de éste estudio.

El trabajo que se presenta es un análisis de algunos textos del autor, a la luz del pensamiento de Michel Foucault acerca del poder desde su origen, características y manifestaciones. Por otra parte, se abordarán algunas teorías y conceptos alrededor del canon de la minificción, el minicuento o microrrelato elaborados por Dolores Koch, Lauro Zavala y Violeta Rojo, con el propósito de observar cómo en esta escritura desgenerada al decir de Rojo, además de la brevedad y la condensación semántica acepta, la hibridación genérica como, la crónica, el grafitti, la poesía, presentes en la obra de Eduardo Galeano.

El tema del poder es de amplio espectro en el campo de la literatura, pues las relaciones que se establecen a través de éste, se encuentran en las múltiples formas como se relacionan los seres humanos en el ámbito, social, cultural, político, ideológico, religioso, sexual, de género, y que la literatura devela en sus imágenes a través de la palabra, de la creación y recreación de mundos que permiten conocer y reconocer en la urdimbre y la trama de esas relaciones, de qué manera se circunscribe el poder en la obra de los escritores.

Las relaciones entre literatura y poder yel polémico tema de la literatura comprometida, es una discusión presente a lo largo de la historia del arte. Por un lado, está la posición acerca de que el escritor debe atender a la creación alejada de cualquier postura ideológica concreta, hasta las corrientes denominadas «el realismo social» $\mathbf{0}$ «la literatura social». Laantigua discusión sobre la unidad de fondo y forma, de la ética y la estética, relacionadas con la calidad expresiva del texto y sus leyes estéticas internas, es inseparable de una ideología subyacente en las obras, sin caer en los excesos del «adoctrinamiento» o el «panfleto», pues se espera de todo escritor una postura definida ante los problemas sociales y políticos de su época.

La obra de Eduardo Galeno podría ser estudiada desde la perspectiva de la tradición marxista respecto de la función social del arte en palabras de Sartre, en ¿Qué es laliteratura $?^{1}$ desde el punto de vista del intelectual revelador que concibe a la

SARTRE, Jean Paul, Situación II, ¿Qué es la literatura?, Buenos Aires:Ed.Losada, 1990. 
literatura como una herramienta social para mostrar las desigualdades e injusticias sociales, para abrir caminos de conciencia social hacia la conquista de una sociedad sin clases; o también desde la mirada de Adorno, otro marxista teórico que se ocupa del objeto estético ${ }^{2}$ y define a la obra de arte como autónoma y anota que no se le puede inducir a la denuncia, sino que su carácter de autonomía confirma ya una praxis, contrario a Sartre al definirla como función social. Adorno fundamenta su afirmación a partir de que las «obras de arte aparecen como heridas sociales, la expresión es el fermento social de la autonomía» es decir, el lenguaje de la forma.

En la obra de Galeano el contexto político y social no puede eludirse, en una entrevista expresa lo siguiente: «Soy un escritor que quisiera contribuir al rescate de la memoria secuestrada de toda América, pero sobre todo de América Latina, tierra despreciada y entrañable ${ }^{3}$ En la mayoría de sus libros la praxis política se hace evidente a través de la expresión, es decir de las formas del lenguaje como vehículo de la literatura, sin embargo, el objeto de estudio, en este trabajo es analizar el tema del poder a partir de cinco propuestas de Foucault que desarrollaremos más adelante; en este caso, las minificciones del autor son susceptibles de ser abordadas desde diversas aristas analíticas como obras estéticas abiertas a diversas interpretaciones.

En consecuencia, abordaremos el corpus de textos desde la expresión de Adorno y el proceso de mímesis que soporta el trabajo de un escritor frente a la realidad. En este sentido, Barthes entiende a la literatura como la práctica de escribir, como el texto o tejido de significantes constituyentes de la obra, en una fuerza o libertad que no dependen del compromiso político del escritor, ni del contenido doctrinario, sino del trabajo de desplazamiento ejercido sobre la lengua, es decir, señala una responsabilidad de la forma que no puede evaluarse en términos ideológicos sino a partir de tres conceptos: Lamathesis, es decir, el marco de comprensión, por cuanto en la literatura están presentes todos los saberes. La mímesis en cuanto representación de la realidad y, la semiosis o interacción de los signos en diversos contextos de la cultura. ${ }^{4}$

Ahora bien, si para Barthes la mediatización de la forma determina que la obra literaria no sea un puro reflejo de la sociedad, también es indiscutible que a través

\footnotetext{
ADORNO, Theodor W, Teoría estética. Madrid: Taurus Ediciones, 1971, pg 352

www.encontrarteaporrea.org/media/59.pdf

BARTHES, Roland, El placer del texto y Lección inaugural. México: Siglo XXI, 1995, p. 124.
} 
del texto más minino, pasa la historia y la sociedad con sus divisiones, conflictos, y problemas. Respectodel tema del poder en la literatura, advierte que el poder en la modernidad era concebido como si fuera uno solo, atribuido a los poseedores, se creía que el poder era objeto exclusivo de la política, y ahora se define el poder como ideológico, capaz de infiltrarse en lo que aparenta ser más invisible. Se pregunta Barthes si el poder fuera plural como los demonios, se podría decir respecto de éste, que «es legión», presente en los más sofisticados mecanismos de intercambio social, no sólo como uso privativo del estado sino también de los grupos, de las modas, la opinión, los espectáculos, los juegos, los deportes, las relaciones familiares y privadas. ${ }^{5}$

De otro lado, la obra de Michel Foucault, ha tenido resonancias a lo largo del siglo XX y XXI, sus elaboraciones sobre la verdad y el poder, los dispositivos de sexualidad y la ética-estética ofrecen nuevas categorías no sólo al pensamiento filosófico sino también a las reflexiones artísticas, científico-sociales y políticas. Exploró los modelos cambiantes de poder dentro de la sociedad y cómo el poder se relaciona con la persona. Estudió también cómo las prácticas diarias permiten a la gente definir sus identidades y sistematizar el conocimiento; los hechos pueden ser entendidos como productos de la naturaleza, del esfuerzo humano o de Dios. Para Foucault, la concepción de las cosas tiene sus ventajas y sus peligros. ${ }^{6}$

Para especificar la presencia del poder en la obra de Galeano, partiremos de cinco proposiciones de Foucault:

1)El poder no es una propiedad que se adquiere, sino un acto que se cumple en un juego de relaciones desiguales y móviles.

2) Las relaciones de poder no tienen una propiedad distintiva. Se las encuentra en todas las relaciones humanas: los procesos económicos, los vínculos con el saber, las relaciones sexuales,etc.

3) El poder no puede enunciarse en los términos de la dominación. La oposición dominadores-dominados es una simplificación abusiva del conjunto de las relaciones de poder que se ejercen en múltiples relaciones de fuerza dentro de la totalidad de las formas del cuerpo social. Es preferible hablar de afrontamiento singular y no de dominación.

4) Hay una racionalidad de las relaciones de poder que las inscribe desde el comienzo en tácticas.

5 Ibid, p. 117

6 FOUCAULT, Michel, El poder de la palabra, en www.epdlp.com/escritor.php?id=1722 
5) Donde hay poder hay resistencia. Las diferentes formas de resistencia no son exteriores al poder, surgen dentro de las relaciones de poder. ${ }^{7}$

Para Graciela Lechuga, la literatura ocupa en Foucault un lugar especial: consagrada a buscar lo cotidiano más allá de sí misma, a traspasar los límites, a descubrir de forma brutal o insidiosa los secretos, a desplazar las reglas y los códigos, a hacer decir lo inconfesable, tendrá por tanto que colocarse ella misma fuera de la ley, o al menos hacer recaer sobre ella la carga del escándalo, de la transgresión o de la revuelta. Más que cualquier otra forma de lenguaje, la literatura sigue siendo el discurso de la «infamia; a ella le corresponde decir lo más indecible, lo peor, lo más secreto, lo más intolerable, lo desvergonzado ${ }^{8}$.

En consecuencia, el corpus de los textos seleccionados gozan de algunas de las consideraciones foucaultianas señaladas por la autora, en tanto desentrañan a través de la imagen literaria y los imaginarios, las infamias del poder, y del lugar de éste como sistema. En el caso de Galeano a través de la síntesis, la denuncia, la crítica, y otras manifestaciones del poder en la sociedad.

\section{Minicuento y minificción}

Para definir la minificción y el minicuento, citaré algunos autores que han desarrollado una aproximación a este género de tan difícil canon literario, pues la variedad y riqueza en su estructura y su expresión, hacen que cada día surjan nuevas denominaciones, diferenciaciones entre uno y otros. Para el caso de, Galeano, estaríamos hablando de minicuentos y minificiones.

Hago la aclaración que hay varios críticos e investigadores que no hacen tal diferenciación. La investigadora Dolores Koch, anota lo siguiente: «Algunas minificciones son muy conocidas como el poema en prosa, la anécdota, la viñeta, la parábola, el aforismo, el epigrama, y otro tipo de minificciones que son inclasificables como ciertos juegos de palabras». Respecto del minicuento expresa que : «por breve que sea, consta, al igual que el cuento, de una exposición o introducción, una situación conflictiva y un desenlace», sobre el micro-relato anota la autora algunas

7 Cfr. LE BLANC, Guillaume. La voluntad de saber.México, Siglo XXI, 1985, p. 123- 127. Citado por Guillaume le Blanc. El pensamiento Foucault. Amorrortu/editores. Buenos Aires, 2008, p. 162

8 LECHUGA Graciela. Las resonancias literarias de Foucault. México:Universidad Autónoma Metropolitana,2004.p.281-282. (, vol 3. 252-253) 
características que lo diferencian del minicuento y la minificción: «la transgresión o fusión de géneros; un desenlace ambivalente o elíptico; alusiones literarias, bíblicas, míticas, históricas, rescate de fórmulas de escritura antigua, fábulas o bestiarios». ${ }^{9}$ Lo cierto es que, hasta el momento, cada día aparecen novedades estilísticas de la brevedad, no solamente por parte de los investigadores, sino de los autores mismos que llaman a sus libros y a sus textos con nombres muy particulares, engrosando así, la familia de este tipo de literatura.

La mayoría de los estudiosos del género, están de acuerdo en el carácter proteico e híbrido de estos textos. Se supone que el minicuentoha heredadoalgunas características del cuento. Veamos qué dice la clásica definición de cuento: El cuento es una narración fingida en todo o en parte, creada por un autor, que se puede leer en menos de una hora y cuyos elementos contribuyen a crear un solo efecto. Si lo tomamos literalmente, en esta definición cabe el minicuento.

La investigadora venezolana Violeta Rojo, en su libro Breve manual para reconocer minicuentos anota las siguientes características:

Brevedad extrema, economía de lenguaje y juego de palabras, representación de situaciones estereotipadas que exigen la participación del lector, carácter proteico ${ }^{10}$.

A su vez, Lauro Zavala, señala otros elementos como diversidad, complicidad, fractalidad, y fugacidad. ${ }^{11}$

\section{Eduardo Galeano: el sistema como poder, entre el realismo y la ironía}

Escritor uruguayo, conocido por su trabajo en el ensayo, la narrativa y la crónica, en particular por su emblemático libro Las venas abiertas de America latina en el que narra la historia de la condición de colonizaje de un continente en manos de los europeos, hasta la AmericaLatina contemporánea, en el llamado postcolonialismo norteamericano.

$9 \mathrm{KOCH}, \mathrm{M}$. Dolores. «Retorno al microrrelato: algunas consideraciones». El cuento en red. México: Revista Electrónica, 2000.

${ }_{10}$ ROJO, Violeta. Breve manual para reconocer minicuentos. México, Universidad Autónoma metropolitana, 1997, p. 8 y 9.

${ }^{11}$ ZAVALA, Lauro. La minifición bajo el microscopio. Bogotá: Universidad Pedagógica Nacional. 2005, p. 59. 
Su trabajo periodístico y comprometido desde sus comienzos, lo llevó al exilio en España por aquellos años de las fatídicas dictaduras en Uruguay, Chile y Argentina en donde escribió Memoria del fuego, una recuperación del pasado indigenista a partir de hechos cotidianos basados en fuentes de la historia, en una re-creación dialógica entre el pasado y el presente.

La obra de Galeano es prolífica. En narrativa breve son muy conocidos: El libro de los abrazos, Los nacimientos, Días y noches de amor y de guerra. De ellos tomaremos algunos textos para entrar en la imagen del poder que se denota en las temáticas referidas a las dictaduras, el exilio, la violación de los derechos humanos, la injusticia e inequidad, el poder de la religión, la familia y los medios de comunicación, la violencia manifiesta en el largo proceso de colonización de los pueblos latinoamericanos.

En este sentido, Galeano ha sido considerado como un escritor comprometido y crítico frente a la historia de América Latina desde su colonia, hasta las nuevas formas de postcolonizaje. Señala no ser un historiador, sino un escritor que quisiera contribuir al rescate de la memoria secuestrada de toda América, pero sobre todo de América Latina, tierra despreciada y entrañable ${ }^{12}$.

La presencia del poder delEstado, de las ideologías y las instituciones en la obra de Galeano es indiscutible. Una de las proposiciones de Foucault para especificar el poder, dice que: «el poder no es una propiedad que se adquiere, sino un acto que se cumple en un juego de relaciones desiguales y móviles». ${ }^{13}$ De esta manera, en algunos textos de El libro de los abrazos, es posible desentrañar estas relaciones de poder a través de la imagen que se construye como mímesis de la realidad vivida en el universo de Galeano.

\section{El estado en América latina}

Hace ya unos años, añares, que el coronel Aménme lo contó.

Resulta que a un soldado le llegó la orden de cambiar de cuartel. Por un año lo mandaron a otro destino, en algún cuartel de frontera,

12 http.//www4.loscuentos.net/cuentos/other/10/16/139

13 LE BLANC, Guillaume. El pensamiento Foucault. Amorrortu/editores. Buenos Aires, 2008, p. 162. 
porque el Superior Gobierno de Uruguay había contraído una de sus periódicas fiebres de guerra al contrabando.

Al irse, el soldado le dejó su mujer y otras pertenencias a su amigo, para que se las tuviera en custodia. Al año volvió y se encontró con que su mejor amigo, también soldado no le quería entregar a su mujer. No había problema en devolver las otras cosas: pero la mujer, no. El litigio iba a resolverse mediante el veredicto del cuchillo, en duelo criollo, cuando el coronel Amén paró la mano.

-Que se expliquen.-Exigió.

- Esa mujer es mía.-Dijo el ausentado.

¿De é l? Habrá sido pero ya no es.-Dijo el otro.

-Razones. Dijo el coronel. -Quiero razones.

Y elusurpador razonó:

-Pero coronel, ¿Cómo se la voy a devolver? ¡Con lo que ha sufrido la pobre! Si viera cómo la trataba este animal...La trataba coronel,...jcomo si fuera del Estado! ${ }^{14}$

El poder en este caso, no lo ha adquirido ni el coronel, ni los soldados, sino que es un juego de relaciones, representado además por la inicial mayúscula de la palabra «Estado». También, el poder implícito en las relaciones de pareja entre los soldados y la mujer, considerada como un objeto, a quien paradójicamente el soldado usurpador, compara con la forma como elEstado trata a sus pertenencias. Lo que caracteriza al poder, expresa Foucault, es que éste pone en juego las relaciones entre los individuos, el término poder designa la manera de relacionarse entre compañeros. ${ }^{15}$

De otra parte, en este minicuento el humor y la sátira, la desacralización del concepto de «Estado» por parte del soldado, el nombre del coronel «Amén», o «así sea» en la traduccióndel latín; el final sorprendente, son elementos literarios, que constituyen al texto en un objeto estético.

14 GALEANO, Eduardo. El libro de los abrazos. México: Siglo XXI 1989, p.43.

15 FOUCAULT, Michel. «El sujeto y el poder» En: Revista de Ciencias Sociales Departamento de Sociología - Facultad de Ciencias Sociales Fundación de Cultura Universitaria Revista No 12 Montevideo,1996, p. 2. 
Varias piezas minificcionales del autor se denominan «El sistema», en las que se representa de varias formas elengranaje del poder. A partir de una microfísica del poder, entendida no como la reducción de elementos visibles, sino como otros tipos de dominio, que no comprenden solamente al Estado; generadora de diferentes tipos de relaciones, móviles y con diversas localizaciones, donde no se encuentra un poder, sino varios poderes, con distintas características de dominación: «Se trata de formas locales, regionales de poder, que poseen su propia modalidad de funcionamiento, procedimiento y técnica» ${ }^{16}$

Veamos el siguiente ejemplo:

\section{«El sistema»}

Que programa la computadora que alarma al banquero que alerta al embajador que cena con el general que emplaza al presidente que intima al ministro que amenaza al director general que humilla al gerente que grita al jefe que prepotea al empleado que desprecia al obrero que maltrata a la mujer que golpea al hijo que patea al perro. ${ }^{17}$

La presencia del poder en otros ámbitos como la burocracia, son temas que también se pueden hallar en este libro de Galeano, en sus textos denominados de esta manera. En «Burocracia/1», se denota la arbitrariedad y el absurdo de los reglamentos escritos por los militares, respecto de las sanciones a los presos políticos, se cuenta la historia de un preso político que es sancionado a cinco días sin visitas ni recreo, por haber violado el reglamento según el cual los presos deben marchar con las manos en la espalda. Este hombre era manco, había perdido su brazo cuando un policía lo tomó preso- al brazo- por lo que elhombre pudo escaparse .En este sentido Deleuze, al analizar el pensamiento de Foucault, anota que el poder del estado no es una ley impuesta o la resultante victoriosa en una guerra ganada por la fuerza. Sería una ley que diferencia distintos tipos de ilegalismos, formalizándolos y consecuentemente generando privilegios, compensaciones y dominios ${ }^{18}$.

La ironía a lo largo del texto, nos muestra la red del poder ejercido sobre los seres en desventaja, el absurdo de las leyes, los reglamentos que se deben cumplir «al pie de la letra», de la que somos testigos a diario en nuestras relaciones con las instituciones, descritas. En esteminicuento que finaliza cuando el preso solicita

16 FOUCAULT, Michel. Las redes del Poder. Buenos Aires, Editorial Lectour, 2005, p. 50.

17 GALEANO, Eduardo. Días de amory de guerra. Argentina, Siglo XXI, 2005, p.45.

18 DELEUZE, Gilles, Foucault, Buenos Aires, Paidós, 2005. pp. 51-56. 
recuperar su brazo perdido y los burócratas le responden ¡que no! porque ese caso está en otro expediente; a él lo procesa la justicia militar, y a su brazo la justicia civil. De igual forma, este aspecto se puede ver en «Burocracia/2»y $\ll$ Burocracia $/ 3{ }^{19}$ con la ironía que delata la irracionalidad de este brazo de poder del Estado.

La imagen del poder del Estado y sus ideologías se expande a través de los textos de Galeano. En Foucault se hacen evidentes en la visibilización del afrontamiento singular, en la especificación del poder, relación que otros circunscriben sólo a lo que llaman»dominación». Al respecto Deleuze observa que el poder carece de atributos para caliûcar y distinguir a los dominantes de los dominados. El poder es operatorio y relacional en términos de relaciones de fuerza que atraviesan las fuerzas dominantes y dominadas, es móvil. ${ }^{20}$

Veamos este texto en el que aflora la condición de muchos seres humanos denominados «nadies».

\section{«Los nadies»}

Sueñan las pulgas con comprarse un perro y sueñan los nadies con salir de pobres, que un mágico día llueva de pronto la buena suerte, que llueva a cántaros la buena suerte; pero la buena suerte no llueve ayer, ni hoy, ni mañana, ni nunca, ni en lloviznita cae del cielo la buena suerte, por mucho que los nadies la llamen y aunque les pique la mano izquierda, o se levanten con el pie derecho, o empiecen el año cambiando de escoba. Los nadies: los hijos de nadie, los dueños de nada. Los nadies: los ninguno, los ninguneados, corriendo la liebre, muriendo la vida, los jodidos, los rejodidos.

Que no son, aunque sean.

Que no hablan idiomas, sino dialectos, Que no profesan religiones, sino supersticiones.

Que no hacen arte, sino artesanía. Que no practican cultura, sino folclore. Que no son seres humanos, sino recursos.

${ }^{19}$ GALEANO, Eduardo. El libro de los abrazos. Siglo XXI,1989, p. 45-47.

${ }^{20}$ DELEUZE, Gilles, Foucault. op, cit, p. 51-56. 
Que no tienen cara, sino brazos.

Que no tienen nombre, sino número.

Que no figuran en la historia universal, sino en la crónica roja de la prensa local.

Los nadies que cuestan menos que la bala que los mata. ${ }^{21}$

Una de las características de la minificción es la mixtura de géneros, como en el anterior ejemplo, en donde la poesía, la fábula y el ensayo se entremezclan o se hacen proteicos. Se podría señalar que en esta minificción, el sentido implícito se encuentra en la presencia tácita del poder de aquellos que se han encargado de subvalorar o minimizar el reconocimiento del otro, de darle categoría de inferior o estigmatizarlo de acuerdo a los valores de uso que representan a su correspondiente ideología y menosprecio, a través de las instituciones culturales, religiosas, militares, empresariales, de los mass media; los nadies encarnados en los seres humanos con mayor desprotección, menos oportunidades, los pobres con sus sueños efímeros, y su esperanza vana de la suerte.

La sociedad de consumo que sostiene el poder económico de las grandes empresas transnacionales, nos ha enseñado el concepto de «desechable» para ciertos productos y objetos, también ha trasladado el concepto a los seres humanos y a los animales, como en la siguiente minificción:

\section{«La civilización del consumo»}

A veces, al fin de la temporada, cuando los turistas se iban a Calella, se escuchaban aullidos desde el monte. Eran los clamores de los perros atados a los árboles.

Los turistas usaban a los perros, para alivio de la soledad, mientras duraban las vacaciones; y después, a la hora de partir, los ataban monte adentro, para que no los siguieran. ${ }^{22}$

Otra mixtura de la minificción con la crónica, se puede observar en el siguiente texto:

\section{«La vida profesional /1»}

A fines de 1987, Héctor Abad Gómez, denunció que la vida de un

21 GALEANO, El libro de los abrazos , op cit., p.52.

22 GALEANO, Eduardo.El libro de los abrazos.op,cit p. 142 
hombre no vale más que ocho dólares. Cuando su artículo se publicó en un diario de Medellín, ya él había sido asesinado. Hector Abad Gómez era el presidente de la Asociación de Derechos Humanos. En Colombia es raro morir de enfermedad.

- ¿Cómo quiere el cadáver sumerced?

El matador recibe la mitad a cuenta. Carga la pistola y se persigna.

Pide a Dios que lo ayude en su trabajo.

Después si no le falla la puntería, cobra la otra mitad. Y en la iglesia, de rodillas, agradece el favor divino. ${ }^{23}$

Respecto de la dominación Foucault expresa:

...por dominación no me refiero al hecho macizo de una dominación global de uno sobre los otros o de un grupo sobre otro, sino a las múltiples formas de dominación que pueden ejercerse dentro de la sociedad: en consecuencia, no al rey en su posición central, sino a los súbditos en sus relaciones recíprocas; no a la soberanía en su edificio único, sino a los múltiples sometimientos que se producen y funcionan dentro del cuerpo social ${ }^{24}$.

De esta manera, se infiere del texto anterior de Galeano, que el poder no está centrado en una persona exclusivamente, sino en núcleos interdependientes para el caso narrado: en el Jefe del Estado, o en el Ministro de Defensa, o en el máximo jefe militar o de inteligencia del estado. El poder circula, delega, y en el peor de los casos contrata sicarios, delincuentes que hacen su trabajo con la bendición de Dios y de la Iglesia, en un carrusel de sometimientos y reciprocidades que funcionan dentro de la sociedad.

Otros tópicos de Galeano enEl libro de los abrazos, está en relación con el sistema bancario, en «La vida profesional/3», la forma como el poder refleja allí lo que el escritor denomina «el terrorismo del dinero», sus funcionarios y tecnócratas mandan en muchos países, deciden sobre el nivel de los salarios y del gasto público, los precios, los impuestos, las inversiones, no se ocupan de las cárceles, ni de los campos de concentración, los tecnócratas se declaran neutrales. ${ }^{25}$ Veamos el siguiente texto brevísimo:

23 Ibid, p.75.

${ }^{24}$ FOUCAULT, Michel, Defender la sociedad. Clase del 14 de enero de 1976.

25 GALEANO, Eduardo, El libro de los abrazos, op, cit, p. 79. 


\section{«Mapamundi/1»}

El sistema:

Con una mano roba lo que con la otra presta.

Sus víctimas:

Cuanto más pagan más deben.

Cuanto más reciben menos tienen.

Cuanto más venden, menos cobran. ${ }^{26}$

El poder de la historia oficial también tiene su cuota en el universo literario de Galeano. Sus textos sobre la desmemoria, el miedo, la amnesia, la imagen percibida en los documentos que registran la historia y sus grandes héroes, no informan sobre Napoleón quien restableció la esclavitud en 1802.En La desmemoria/3 los negros se muestran como los nietos de Napoleón, no como sus víctimas. ${ }^{27}$

Uno de los recursos literarios más utilizados en las minificciones y los minicuentos es la ironía, ese juego en el que se burla de lo que aparentemente se alaba: Dios, el Gobierno, loscuras, los expertos, la civilización;ya el títuloes la mayor ironía. Poder de la literatura y del escritor para develar el poder en sus distintas manifestaciones.

\section{«Elogio del sentido común»}

$\mathrm{Al}$ amanecer de un día de fines de 1985, las radios colombianas informaron:

La ciudad de Armero ha sido borrada.

El volcán vecino la mató. Nadie pudo correr más rápido que la avalancha de lodo ardiente: una ola grande como el cielo y caliente como el infierno atropelló a la ciudad, echando humo y rugiendo furias de mala bestia, y se tragó a treinta mil personas y a todo lo demás.

El volcán venía avisando desde hacía un año. Un año entero estuvo echando fuego, y cuando ya no podía esperar más, descargó sobre la ciudad un bombardeo de truenos y una lluvia de ceniza, para que

${ }^{26}$ Ibid, , p. 80.

27 Íbid, p. 86. 
escucharan los sordos y vieran los ciegos tanta advertencia. Pero el alcalde decía que el Superior Gobierno decía que no hay motivos de alarma, y el cura decía que el obispo decía que Dios se está ocupando del asunto, los geólogos y los vulcanólogos decían que todo está bajo control y fuera de peligro.

La ciudad de Armero murió de civilización. No había cumplido todavía un siglo de vida. No tenía himno ni escudo. ${ }^{28}$

El texto anterior, connota el poder de las personas que representan las instituciones en este caso, el Estado, la ciencia y la iglesia, quienes tienen el poder de autorizar los avisos de emergencias y desalojos, la responsabilidad de velar por la seguridad y la vida de los ciudadanos, circunstancia que se repite con cierta frecuencia en la América Latina. Así, se comprueba una vez más la forma como el poder actúa a través de las múltiples relaciones de fuerza dentro del cuerpo de la sociedad, el poder es poder porque circula o funciona en cadena, como anota Foucault. ${ }^{29}$

Al contrario, expresa el autor, se trata de captar el poder en sus extremos, es decir, tomar el poder en sus formas y sus instituciones más regionales, más locales, sobre todo donde ese poder, al desbordar las reglas del derecho que lo organizan y lo delimitan, se prolonga, por consiguiente, más allá de ellas, se inviste de unas instituciones, cobra cuerpo en unas técnicas y se da instrumentos materiales de intervención, eventualmente, incluso, violentos ${ }^{30}$. Se podría también denominar como el poder de ciertos feudos o «los mandos medios», que se puede sentir y evidenciar en la cotidianidad del trabajo y de la organización de las empresas y las instituciones.

Utilizando la sátira, otro tema en la obra de Galeano es la crítica a la alienación, como un resultado del ejercicio del poder

\section{«Alienación/1»}

Creen los que mandan que mejor es quien mejor copia. La cultura oficial exalta las virtudes del mono y del papagayo. La alienación en América Latina: Un espectáculo de circo. Importación, impostación. Nuestras ciudades están llenas de arcos de triunfos, obeliscos y

28 Ibid, p. 98.

29 FOUCAULT. Michel. Defender la sociedad.Op. citp.

30 Ibid, 
partenones. Bolivia no tiene mar pero tiene almirantes disfrazados de lord Nelson. Lima no tiene lluvia pero tiene techos a dos aguas y canaletas. En Managua una de las ciudades más calientes del mundo, condenada al hervor perpetuo, hay mansiones que ostentan soberbias estufas de leña, y en las fiestas de Somoza las damas de ciudad lucían estolas de zorro plateado. ${ }^{31}(1998,121)$

Para Frye los rasgos específicos de la sátira se formalizan en la crítica al hombre y a su entorno a través de la alegoría, la ironía y el humor. ${ }^{32}$ De esta manera, Galeano en sus minificciones tiene una actitud crítica hacia las diversas formas del poder que se reflejan en las costumbres, en la visión de mundo, en las expresiones culturales como la música, la comida, el arte, y en el caso de texto anterior, de las ciudades y su arquitectura impostada o importada de otros países y otras culturas, para respaldar los gustos y las modas de gobiernos e ideologías mediante la imposición de objetos, artefactos y costumbres foráneas y ajenas por parte de «los que mandan»; fenómeno extendido en toda la América Latina en su condición de subdesarrollo y más aún en tiempos de globalización y de neoliberalismo.

Decíamos al comienzo, en compañía de Foucault, que las relaciones de poder se las encuentra en todas las relaciones humanas. Examinemos ahora cómo estas relaciones están presentes con sus distintos dispositivos, a través de la educación, la religión, los medios de comunicación, en algunas de las minificciones, de El libro de los abrazos:

\section{«La televisión/2»}

La televisión, ¿muestra lo que ocurre?

En nuestros países la televisión muestra lo que ella quiere que ocurra; y nada ocurre si la televisión no lo muestra.

La televisión, esa última luz que te salva de la soledad y de la noche, es la realidad. Porque la vida es un espectáculo: a los que se portan bien, el sistema les promete un cómodo asiento. ${ }^{33}$

31 GALEANO, Eduardo.El libro de los abrazos. Op.cit, p.113.

32 NORTROPH, Frye. Anatomía de la crítica.Cuatro ensayos. Caracas, Monteavilaeditores, 2001, p. 295.

33 GALEANO, Eduardo. El libro de los abrazos.Op, cit, p.137. 
La manipulación de los medios de comunicación ha sido un dispositivo poderoso; no en vano se habla del cuarto poder, y en nuestro continente ha sido una de las formas de filtrar la información y la verdad de la realidad social, cultural y política; es una de las formas de la alienación no sólo para disfrazar la realidad, sino para crear adicciones al consumo de los productos de las transnacionales; en este sentido Foucault dice que hay una racionalidad de las relaciones de poder que las inscribe desde el comienzo en tácticas, como se anota cuando enumeramos los postulados de este filósofo en el apartado sobre Literatura y poder.

Galeano en varios de sus textos nombra al sistema, como ese ente abstracto, conformado por todos aquellos que manejan el poder y aquellos sobre los cuales es ejercido el poder. También se encuentra el tema de la religión como otro dispositivo mediante el cual las fuerzas del poder despliegan sus territorios. «En teología/ $1 »^{34} \mathrm{y}$ «Teología/2», Galeano desacraliza la imagen delDios todopoderoso de los cristianos, ese Dios que enseña a través del catecismo a tener miedo y a creer, a prometer cielos e infiernos, a prodigar la culpa en la mente inocente de los niños como en «Cultura del terror/4» ${ }^{35}$ a través de las enseñanzas de la Iglesia como institución, algunos de ellos con el ingrediente del humor y la ironía.

\section{«Teología/2»}

El Dios de los cristianos, Dios de mi infancia no hace el amor. Quizás es el único Dios que no ha hecho el amor, entre todos los dioses de todas las religiones de la historia humana. Cada vez que lo pienso siento pena por él. Y entonces le perdono que haya sido mi superpapá castigador, jefe de policía del universo, y pienso que al fin y al cabo, Dios también supo ser mi amigo en aquellos viejos tiempos cuando yo creía en él y creía que el creía en mi. Entonces paro la oreja a la hora de los rumores mágicos, entre la caída del sol y la caída de la noche, y me parece escuchar sus melancólicas confidencias. ${ }^{36}$

Galeano nombra varios de sus textos como «La cultura del terror», para referirse en general al sistema como un gran organismo de poder, y en particular a la educación como un dispositivo de control desde sus distintos campos: el religioso, el escolar y el familiar, que construye unos modelos de comportamiento para ser repetidos en

34 Ibid., p. 74.

35 Ibid, .p.75.

36 Ibid, p.63. 
consonancia con ciertas normas y reglas afines a intereses de poder y sujeción de los otros, como en Celebración de las bodas de la razón y elcorazón, en donde se hace una crítica a la educación que ha divorciado el alma del cuerpo, al corazón de la razón y elogia a los pescadores colombianos que llamaron sentipensanteal lenguaje que dice la verdad ${ }^{37}$

\section{«La Cultura del terror/3»}

Sobre la niña ejemplar:

Una niña juega con dos muñecas y las regaña para que se queden quietas. Ella también parece una muñeca, por lo linda y buena que es y porque a nadie molesta.

(Del libro Adelante de J.H.Figueira, que fue texto de enseñanza en las escuelas del Uruguay hasta hace pocos años.) ${ }^{38}$

Dentro de esta «cultura del terror», se encuentra además, el tema de los indígenas y su colonizaje, el maltrato y desconocimiento al que han sido sometidos, la condición de enajenados sin derechos, bajo la autoridad de las hegemonías políticas, sociales, culturales y religiosas que a lo largo de la historia han creado anclajes de poder, inclusive desde la nominación y el uso del lenguaje. Recuperación del pasado indigenista construida por Galeano en «Los nacimientos».

\section{«Los indios/2»}

El lenguaje como traición; les gritan verdugos. En el Ecuador los verdugos llaman verdugos a sus víctimas:

-Indios verdugos, les gritan. De cada tres ecuatorianos uno es indio. Los otros dos le cobran, cada día la derrota histórica.

-Somos los vencidos, nos ganaron la guerra. Nosotros perdimos por creerles. Por eso, -me dice Miguel nacido en lo hondo de la selva amazónica.

Los tratan como a los negros en Sudáfrica: los indios no pueden entrar a los hoteles ni a los restaurantes.

${ }^{37}$ Ibid, p. 89.

${ }^{38}$ Ibid, p. 108. 
-En la escuela me metían palo cuando hablaba nuestra lengua, -me cuenta Lucho, nacido al sur de la sierra.

-Mi padre me prohibía hablar quichua. Es por tu bienme decía, -recuerda Rosa, la mujer de Lucho.

Rosa y Lucho viven en Quito, están acostumbrados a escuchar:

-Indio de mierda

Los indios son tontos, vagos, borrachos, Pero el sistema que los desprecia, desprecia lo que ignora porque ignora lo que teme. Tras la máscara del desprecio, asoma el pánico, estas voces antiguas, porfiadamente vivas, ¿Qué dicen? ¿Qué dicen cuando hablan? ¿Qué dicen cuando callan? ${ }^{39}$

Las minificciones de Galeano son de carácter realista, fruto de su experiencia como periodista y escritor, pero también como exiliado de su país en la época de las dictaduras latinoamericanas en la década de los años sesenta y setenta en Chile, Uruguay, Paraguay, Brasil y Argentina. Dentro de «la cultura del terron» se manifiesta esa página terrible por todos conocida, acerca de las torturas y vejámenes infligidos a tantas personas contrarias e inocentes frente a los regímenes dictatoriales, otra sombra del poder político en la América Latina, que se refleja en la vida de familia.

\section{«La cultura del terror $/ 2 »$}

La extorsión,

Elinsulto,

La amenaza,

El coscorrón,

La bofetada,

La paliza,

Elazote,

El cuarto oscuro,

La ducha helada,

El ayuno obligatorio,

${ }^{39}$ Ibid, p. 100 . 
La comida obligatoria,

La prohibición de salir,

La prohibición de decir lo que se piensa,

La prohibición de hacer lo que se siente,

Y la humillación pública

Son algunos de los métodos de penitencia y tortura tradicionales en la vida de familia. Para castigo de la desobediencia y escarmiento de la libertad, la tradición familiar perpetúa una cultura del terror que humilla a la mujer, enseña a los hijos a mentir, y contagia la peste del miedo.

-Los derechos humanos tendrían que empezar por casa, me comenta en Chile, Andrés Domínguez. ${ }^{40}$

Respecto del tema de las torturas y del castigo en las dictaduras del cono sur, infligidas a los presos políticos y no políticos, como una estrategia para confesar, denunciar, admitir, se creó toda una técnica efectiva. El cuerpo ha sido un instrumento en manos del poder, según Foucault, el cuerpo se convierte en fuerza útil cuando es a la vez cuerpo productivo y cuerpo sometido, pero ese sometimiento puede ser sutil, calculado, pensado, organizado, sin hacer uso de las armas y del terror, como se aprecia en las formas de castigo y sometimiento de la familia en la minificción anterior. Para Foucault, puede existir un «saber» del cuerpo que no es exacta-mente la ciencia de su funcionamiento, y un dominio de sus fuerzas que es más que la capacidad de vencerlas: este saber y este dominio constituyen lo que podría llamarse la tecnología política del cuerpo. ${ }^{41}$

Galeano hace mención a estas circunstancias de una manera más bien mesurada, es muy cuidadoso en las descripciones, apenas menciona la cárcel, los interrogatorios, los fusilamientos, el miedo; sin embargo, a través de estas nominaciones, se puede inferir lo que el cine, la crónica, la novela, la poesía ha mostrado con más intensidad.

La quinta proposición de Foucault para especificar el poder, expresa: donde hay poder hay resistencia, ésta no es externa al poder, sino que surge dentro de las relaciones de poder. En este sentido, la obra de Galeano es un ejemplo de resistencia; en general, el arte, es una expresión de resistencia frente al poder fascista, totalitario o de las dictaduras. El escritor expresa respecto de El libro de los abrazos, :Creo

${ }^{40}$ Ibid, p. 107.

${ }^{41}$ FOUCAULT; Michel.Vigilary castigar. Buenos Aires, Siglo XXI, 2003 p. 27. 
que un autor al escribir, abraza a los demás. Y este es un libro sobre los vínculos con los demás, los nexos que la memoria ha conservado, vínculos, de amor, de solidaridad. Historias verdaderas vividas por mi y por mis amigos, y como la memoria está llena de tantas personas, es al mismo tiempo un libro de muchos. ${ }^{42}$

Una buena parte de El libro de los abrazos, hace parte de la resistencia desde la amistad, la solidaridad, el amor, la esperanza y la risa, frente a los embates siniestros del poder. Podríamos decir que en la resistencia hay un gran poder, un poder para la vida, la libertad y la justicia, en textos como «Celebración de la voz humana/2», en donde se narra cómo en tiempos de la dictadura uruguaya, los presos inventaron el alfabeto de los dedos para comunicarse, o los golpecitos en la pared para que la voz humana saliera por las manos y así compartir sueños, esperanzas, también miedos ${ }^{43}$; o en «Crónica de la ciudad de Santiago», en donde se narra la resistencia conmovedora de un mendigo que decía al desplazarse por las calles en tiempos de Pinochet: Soy civil. ${ }^{44}$

También se encuentra presencia de la resistencia frente al poder y abuso militar en textos alusivos en «Neruda/2» y su casa de Valparaíso en donde después de la muerte del poeta, aleteaba con violencia un águila, metáfora de la fuerza del poeta, viva en su poesía. ${ }^{45} \mathrm{En}$ «Celebración de la amistad $/ 1 »{ }^{46}$ se refiere al exilio de Benedetti cuando vivía en Buenos Aires, pues allí tenía cinco llaves de cinco casas, de cinco de sus amigos que le salvaron. En «Gelman» ${ }^{47}$ relata la vida trágica de Juan Gelman: la persecución y asesinato de su familia, cuando se encontraba exiliado, y sin embargo renace de la ceniza con su maravillosa obra poética. En «Desafío», ${ }^{48}$ expone el miedo que invadió a las personas víctimas de las dictaduras y, sin embargo, después de todo, no lograron convertirlas en ellas.

Otra expresión de la resistencia en las minificciones del autor, deviene en algunas de ellas denominadas «Dicen las paredes», a partir de los grafittis que personas anónimas escriben en las paredes :

${ }^{42} \mathrm{Http} / / \mathrm{www} 4$. loscuentos.net/cuentos/other

${ }^{43}$ GALEANO, Eduardo,El libro de los abrazos .op.cit p. 163

${ }^{44}$ Ibid, p. 21.

45 Ibid, p. 25.

46 Ibid, p. 186.

${ }^{47}$ Ibid, p. 189.

${ }^{48}$ Ibid, p. 242. 


\section{«Dicen las paredes/2»}

En Buenos Aires, en el puente de La Boca:

Todos prometen y nadie cumple. Vote por nadie.

En Caracas, en tiempos de crisis, a la entrada de uno de los barrios más pobres:

Bienvenida, clase media.

En Bogotá a la vuelta de la Universidad Nacional:

Dios vive.

Y debajo con otra letra:

De puro milagro.

Y también en Bogotá:

¡Proletarios de todos los países uníos!

Y debajo con otra letra:

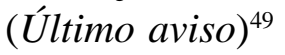

El humor como otra forma de resistencia se puede evidenciar en los muros de las ciudades con gran ingenio, crítica y sarcasmo, también dan cuenta de la presencia del poder político en los pueblos latinoamericanos, imágenes que dan origen a la obra literaria de Galeano y representan la historia y el devenir de las luchas desde distintos contextos y alusiones.

Para concluir, el concepto del poder desde el pensamiento de Foucault en sus cinco proposiciones acerca del origen, la naturaleza y el lugar de sus manifestaciones, se puede evidenciar y relacionar con la obra literaria de Eduardo Galeano desde el punto de vista político, social, cultural e ideológico, a través del sentido implicado y literal de las diversas minificciones y minicuentos de su obra, además de consolidarse como literatura, hacen parte de la historia no oficial de los pueblos de la América Latina.

\section{Bibliografía}

ADORNO, Theodor W. Teoría Estética. Madrid: Taurus, 1971.

BARTHES, Roland, El placer del texto y Lección inaugural. México: Siglo XXI, 1995.

${ }^{49}$ Ibid, p. 87. 
DELEUZE, Gilles, Foucault, Buenos Aires, Paidós, 2005.

LE BLANC, Guillaume. El pensamiento Foucault. Amorrortu/editores. Buenos Aires, 2008.

LECHUGA Graciela. Las resonancias literarias de Foucault. México, Universidad Autónoma Metropolitana. 2004.

FOUCAULT, Michel,»El sujeto y el poder» En: Revista de Ciencias Sociales Departamento de Sociología-Facultad de Ciencias Sociales Fundación de Cultura Universitaria Revista Nº 12 Montevideo, 1996.

Las redes del Poder, Buenos Aires, Editorial Lectour, 2005.

Defender la sociedad. Clase del 14 de enero de 1976.

Vigilar y castigar. Buenos Aires, Siglo XXI, 2003.

GALEANO, Eduardo. El libro de los abrazos. MéxicoSiglo XXI 1989.

Días de amor y de guerra. Argentina, Siglo XXI, 2005.

NORTROPH, Frye. Anatomía de la crítica. Cuatro ensayos. Caracas, Monteavila editores, 2001.

ROJO, Violeta. Breve manual para reconocer minicuentos. México: Universidad Autónoma metropolitana, 1997.

SARTRE, Jean Paul. ¿Qué es la literatura?Buenos Aires, Losada, 1990.

ZAVALA, Lauro. La minifición bajo el microscopio. Bogotá: Universidad Pedagógica Nacional, 2005.

g Foucault, Michel, El poder de la palabra www.epdlp.com/escritor.php?id=1722 www4.loscuentos.net/cuentos/other/10/16/139

www4.loscuentos.net/cuentos/other 